\title{
Jak rozpoznajemy ostrą zatorowość płucną na Oddziałach Intensywnego Nadzoru Kardiologicznego?
}

\author{
How do we diagnose acute pulmonary embolism in Cardiac Intensive Care Units?
}

\author{
Joanna Mikocka, Janusz Sielski \\ Świętokrzyskie Centrum Kardiologii, Kielce
}

\section{Streszczenie}

ŻyIna choroba zakrzepowo-zatorowa obejmuje dwie jednostki chorobowe: zakrzepicę żył głębokich oraz zatorowość płucną. Jest trzecią co do częstości występowania chorobą układu krążenia - według najnowszych statystyk roczna zapadalność na nią wynosi 100-200 na 100000 osób. W większości przypadków ZP jest następstwem zakrzepicy żył głębokich kończyn dolnych, natomiast niezakrzepowa ZP występuje dość rzadko. Czynnikami predysponującymi do żylnej choroby zakrzepowo-zatorowej są czynniki osobnicze czyli stałe - związane z chorym oraz czynniki czasowe powiązane z różnymi sytuacjami klinicznymi. Zatorowość płucna może być również idiopatyczna i wystąpić przy braku jakiegokolwiek znanego czynnika ryzyka. W niniejszej pracy zaprezentowano etiopatogenezę, patofizjologię oraz objawy ZP. Praca będzie użyteczna dla lekarzy dyżurujących w oddziałach ratunkowych oraz oddziałach kardiologii i chorób wewnętrznych Przyczyni się do bardziej trafnego rozpoznawania tej ważnej jednostki chorobowej.

Słowa kluczowe: żylna choroba zakrzepowo-zatorowa, zatorowość płucna

Folia Cardiologica 2018; 13, 4: 309-317

\section{Wprowadzenie}

Żylna choroba zakrzepowo-zatorowa obejmuje dwie jednostki kliniczne: zakrzepicę żył głębokich oraz zator tętnicy płucnej. Jest trzecią co do częstości występowania chorobą układu krążenia. Według najnowszych statystyk roczna częstotliwość incydentów zatoru płucnego wynosi 100-200 na 100000 osób [1, 2]. Zatorowość płucna bywa śmiertelna w swej ostrej fazie. Może również występować jako postać przewlekła i prowadzić do niepełnosprawności [3, 4]. Ostra zatorowość płucna stanowi najgroźniejszą postać kliniczną żylnej choroby zakrzepowo-zatorowej. Prawdopodobieństwo wczesnego zgonu w zatorowości płucnej wysokiego ryzyka wynosi ponad 15\%, w zatorowości płucnej pośredniego ryzyka 3-15\%, a w zatorowości płucnej niskiego ryzyka jest mniejsze niż 1\% [5, 6]. Zdarza się, że zatorowość płucna przebiega bez żadnych objawów klinicznych i zdiagnozowana może zostać zupełnie przypadkowo. Ponadto ZP stwierdza się często w badaniu pośmiertnym u pacjentów, którzy byli leczeni z powodu innych chorób [7].

W niniejszej pracy zaprezentowano etiopatogeneze, patofizjologię oraz objawy ZP. Nakreślono symptomy, które mogą prowadzić do rozpoznania tej choroby. Praca ta, według autorów, będzie użyteczna dla lekarzy dyżurujących w oddziałach ratunkowych oraz oddziałach kardiologii i chorób wewnętrznych. Przyczyni się do bardziej trafnego rozpoznawania tej ważnej jednostki chorobowej.

Adres do korespondencji: lekarz rezydent Joanna Mikocka, Świętokrzyskie Centrum Kardiologii, Oddział Intensywnej Opieki Kardiologicznej, ul. Grunwaldzka 45, 25-736 Kielce, e-mail: joannaz86@onet.pl 


\section{Epidemiologia}

Na podstawie danych epidemiologicznych zator tętnicy płucnej stanowi jedną z najczęstszych przyczyn hospitalizacji w państwach europejskich. Badania epidemiologiczne pokazały, że w Polsce na zakrzepicę żył głębokich zapada około 50 tys. osób w ciągu roku, a u około 20 tys. występuje objawowa zatorowość płucna [8]. Badania prowadzone we Francji dowiodły, że zakrzepica żył głębokich występuje u około 120 na 100000 osób w ciągu roku, a roczna częstotliwość zatorowości płucnej wynosi 60-111 na 100000 osób [9].

Wskaźnik zapadalności na zatorowość płucną zależy od wieku badanej populacji i wzrasta wraz z nim, a począwszy od 40 roku życia rośnie dwukrotnie w każdej kolejnej dekadzie życia [10]. Według statystyk wskaźnik zachorowalności na ZP u dzieci wynosi 1 na 100 000, u młodzieży 30 na 100 000, a u osób po 70 roku życia 500 na 100000 w ciągu roku [11].

\section{Etiopatogeneza}

Najczęściej zatorowość płucna jest wynikiem zakrzepicy żył głębokich kończyn dolnych. U ponad połowy pacjentów materiał zatorowy pochodzi z proksymalnego odcinka żył głębokich kończyn dolnych, a tylko u jednej czwartej chorych z dystalnych odcinków żył głębokich. Rzadziej zatory pochodzą z żył powierzchownych, z żył kończyn górnych i z żył miednicy mniejszej [12]. Niezakrzepowa postać ZP występuje rzadko.

Czynnikami predysponującymi do żylnej choroby zakrzepowo-zatorowej są czynniki kliniczne, biochemiczne, wrodzone i nabyte $[13,14]$. W zależności od stopnia zagrożenia zakrzepowego wyróżniamy czynniki ryzyka duże, umiarkowane oraz małe [15]. Około 30\% przypadków stanowi idiopatyczna ZP, która może wystąpić bez jakichkolwiek czynników ryzyka u chorego [16].

Do klinicznych czynników zaliczamy: wiek, unieruchomienie, nowotwory złośliwe, zaawansowaną niewydolność serca, niewydolność oddechową, otyłość, żylaki kończyn dolnych, epizod żylnej choroby zakrzepowo-zatorowej w przeszłości, hormonoterapię, udar mózgu z następczym niedowładem lub porażeniem kończyn, nikotynizm. Do czynników biochemicznych zaliczamy trombofilie wrodzone i nabyte $[13,14]$.

W skład dużych czynników ryzyka ZP wchodzą: duże zabiegi operacyjne, rozległe urazy, złamanie w obrębie miednicy lub kończyn dolnych, uszkodzenie rdzenia kręgowego, zawał serca oraz przebyta żylna choroba zakrzepowo-zatorowa.

Do umiarkowanych czynników ryzyka ZP należą: operacja artroskopowa stawów kolanowych, choroby autoimmunologiczne, centralne cewniki żylne, przewlekła niewydolność serca, niewydolność oddechowa, hormonalna terapia zastępcza, doustna antykoncepcja, zapłodnienie in vitro, ciąża i połóg, udar porażenny, przebyta żylna choroba zakrzepowo-zatorowa, transfuzje krwi, chemioterapia, nowotwory złośliwe - szczególnie w zaawansowanym stadium choroby.

Ryzyko ZP różni się w zależności od rodzaju nowotworu złośliwego [17]. Nowotwory płuc, żołądka, jelit, trzustki, mózgu oraz nowotwory hematologiczne wiążą się z najwyższym ryzykiem ZP. U kobiet w wieku rozrodczym antykoncepcja doustna jest najczęstszym czynnikiem ryzyka tego schorzenia $[18,19]$. Największe ryzyko ZP występuje $w$ trzecim trymestrze ciąży i do 6 tygodni po porodzie [20].

Wśród małych czynników ryzyka ZP można wymienić: cukrzyce, nadciśnienie tętnicze, unieruchomienie związane z przebywaniem w pozycji siedzącej (np. podczas podróży samochodem lub samolotem), pozostawienie w łóżku dłużej niż 3 dni, operacje laparoskopowe, otyłość, żylaki, ciążę, starszy wiek [20].

\section{Patofizjologia}

Wpływ na wystąpienie ŻChZZ mają trzy główne czynniki: zwolnienie przepływu krwi żylnej, nieprawidłowości w budowie ściany żylnej oraz zmiany w składzie krwi powodujące nadmierną aktywność układu krzepnięcia i upośledzenie układu fibrynolitycznego - tzw. triada Virchowa [21]. Ostra zatorowość płucna powoduje zmiany w krążeniu krwi oraz wymianie gazowej, a odpowiedź hemodynamiczna na zator tętnicy płucnej zależy od wielkości materiału zatorowego, współistniejących chorób płuc, serca oraz odpowiedzi neurohumoralnej. Zamknięcie lub zwężenie światła tętnicy płucnej o około 30-50\% skutkuje skurczem tętnic płucnych, co doprowadza do hipoksji i wzrostu oporu w łożysku płucnym [22].

Zmiany te powodują wzrost obciążenia następczego prawej komory, a nagły wzrost ciśnienia w prawej komorze prowadzi do jej poszerzenia i hipokinezy (obniża się efektywność skurczu mięśnia prawej komory zgodnie z prawem Franka-Starlinga) oraz powstania fali zwrotnej przez zastawkę trójdzielną. Zmiany te mogą doprowadzić do rozwoju objawowej niewydolności prawokomorowej. Lewostronne przesunięcie przegrody międzykomorowej powoduje upośledzenie napełniania lewej komory, co może być przyczyną hipotensji lub wstrząsu.

Powyższe zmiany prowadzą do zaburzenia stosunku między wentylacją a perfuzją oraz zwiększenia przestrzeni martwej co skutkuje utrudnieniem wymiany gazowej. Zmiany te powodują zaburzenia równowagi kwasowo-zasadowej. Hipoksemii towarzyszy hiperwentylacja, która powoduje hipokapnię i zasadowicę oddechową [23].

\section{Klasyfikacja ZP}

Kliniczna klasyfikacja stopnia ciężkości ostrej ZP opiera się na szacowanym ryzyku zgonu. Określa się ją na podstawie 
śmiertelności szpitalnej lub 30-dniowej po zakończeniu hospitalizacji.

Klasyfikacja ciężkości ZP ma istotne znaczenie dla wykonania diagnostyki, wdrożenia odpowiedniego leczenia oraz oceny rokowania u chorego. Na podstawie stanu klinicznego pacjenta różnicuje się ją na ZP wysokiego ryzyka - gdy występuje wstrząs bądź hipotonia, lub ZP niewysokiego ryzyka - jeśli brak tych objawów $[6,7]$. Zatorowość płucna niewysokiego ryzyka stanowi 90-95\% przypadków [24].

\section{Objawy}

Objawy ZP zarówno podmiotowe jak i przedmiotowe moga być niespecyficzne, co może utrudnić rozpoznanie. Objawy, które pojawiają się w tej chorobie, mogą również towarzyszyć zawałowi serca, zapaleniu płuc, ostrej niewydolności lewokomorowej, tamponadzie serca lub rozwarstwieniu aorty (ryc. 1).

U dużej liczby chorych z ZP występują takie objawy jak: duszność, omdlenie lub stan przedomdleniowy, ból w klatce piersiowej, kaszel [25]. Hipotensja i wstrząs występują znacznie rzadziej, ale są bardzo istotne klinicznie, ponieważ wskazują na centralną postać ZP. W centralnej ZP duszność może być nasilona w znacznym stopniu, natomiast w przypadku małej i obwodowej ZP zwykle ma charakter łagodny i może pojawić się okresowo u chorego. U pacjentów obciążonych kardiologicznie, z niewydolnością serca lub chorobami płuc, nasilenie duszności może być jedynym objawem klinicznym.

Omdlenie rzadko towarzyszy ZP. Może ono występować niezależnie od obecności niestabilności hemodynamicznej [26]. Zatorowość płucna może być też bezobjawowa i zostać wykryta w trakcie diagnozowania innych chorób, bądź też w badaniu pośmiertnym.

Dolegliwości bólowe w klatce piersiowej i kaszel są częstymi objawami ZP. Spowodowane są podrażnieniem opłucnej przez zatory obwodowe, które prowadzą do zawału płuca [27]. Ból w klatce piersiowej może być podobny do bólu w ostrym zespole wieńcowym. Zatorowość płucna wymaga różnicowania z ostrą dysfunkcją zastawek, zawałem serca, tamponadą i rozwarstwieniem aorty.

Hipoksemia w badaniu gazometrycznym uważana jest za jeden z głównych objawów ostrej ZP, ale u 40\% chorych występuje prawidłowa saturacja tlenem, a u 20\% prawidłowy gradient pęcherzykowo-włośniczkowy $[28,29]$. W gazometrii obecna jest także hipokapnia. Zdjęcie RTG klatki piersiowej, choć często jest niespecyficzne, to pozwala na wykluczenie innych przyczyn duszności czy bólu w klatce piersiowej [30].

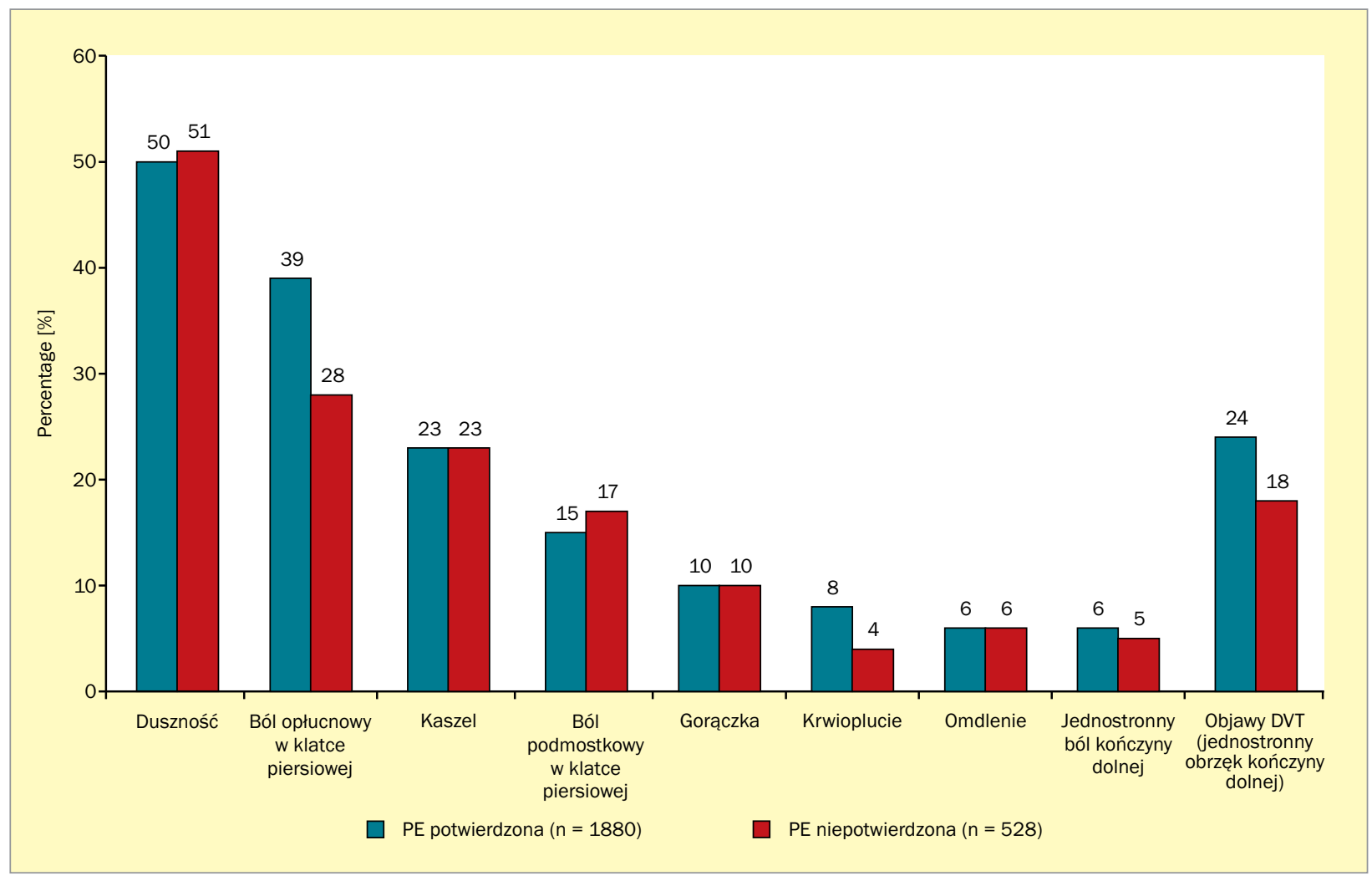

Rycina 1. Charakterystyka kliniczna chorych z podejrzeniem zatorowości płucnej w izbie przyjęć [5] . DVT (deep vein thrombosis) - zakrzepica żył głębokich; PE (pulmonary embolism) - zatorowość płucna 
W ZP wysokiego ryzyka w badaniu EKG występuja zmiany wskazujące na przeciążenie prawej komory m.in. niezupełny lub całkowity blok prawej odnogi pęczka Hisa, odwrócenie załamka T w odprowadzeniach V1-V5, zespół QR w V1, zespół S1Q3T3 [31].

W ZP niewysokiego ryzyka jedyną nieprawidłowością w zapisie EKG może być tachykardia zatokowa (ok. 40\% pacjentów) oraz nadkomorowe zaburzenia rytmu serca $\mathrm{np}$. migotanie przedsionków [32].

\section{Rozpoznanie}

Ocena prawdopodobieństwa zatorowości płucnej jest bardzo ważnym elementem w diagnostyce. Zatorowość płucną można ocenić za pomocą skali Wellsa oraz skali genewskiej (tab. 1). Według obydwu tych skal odsetek pacjentów, u których można spodziewać się potwierdzonej ZP wynosi około 10\% w kategorii niskiego prawdopodobieństwa, 30\% w kategorii pośredniego prawdopodobieństwa oraz 65\% w kategorii wysokiego prawdopodobieństwa [33, 34].

W celu przewidywania wewnątrzszpitalnego lub 30-dniowego rokowania u chorych bierze się pod uwage ryzyko związane z ZP, schorzenia towarzyszące oraz stan kliniczny chorego [35].

U chorych bez objawów wstrząsu lub niedociśnienia, gdy nie występuje wysokie ryzyko złego rokowania, należy ocenić wskaźnik predykcji ryzyka klinicznego [35]. Służy do tego skala PESI i sPESI, zawierająca takie elementy jak:

Tabela 1. Skale wykorzystywane w ocenie klinicznego prawdopodobieństwa zatorowości płucnej [5]

\begin{tabular}{|c|c|c|}
\hline \multirow{2}{*}{$\begin{array}{l}\text { Cecha } \\
\text { Skala Wellsa }\end{array}$} & \multicolumn{2}{|c|}{ Reguła przyznawania punktów na podstawie decyzji kliniczne } \\
\hline & Wersja oryginalna [95] & Wersja uproszczona [107] \\
\hline PE lub DVT w wywiadzie & 1,5 & 1 \\
\hline Tętno $\geq 100 / \mathrm{min}$ & 1,5 & 1 \\
\hline Operacja lub unieruchomienie w ciągu ostatnich 4 tygodni & 1,5 & 1 \\
\hline Krwioplucie & 1 & 1 \\
\hline Aktywna choroba nowotworowa & 1 & 1 \\
\hline Objawy kliniczne DVT & 3 & 1 \\
\hline Alternatywna diagnoza jest mniej prawdopodobna niż PE & 3 & 1 \\
\hline \multicolumn{3}{|l|}{ Prawdopodobieństwo kliniczne } \\
\hline \multicolumn{3}{|l|}{ Podział trzypoziomowy } \\
\hline Niskie & $0-1$ & Brak danych \\
\hline Pośrednie & $2-6$ & Brak danych \\
\hline Wysokie & $\geq 7$ & Brak danych \\
\hline \multicolumn{3}{|l|}{ Podział dwupoziomowy } \\
\hline PE mało prawdopodobna & $0-4$ & $0-1$ \\
\hline PE prawdopodobna & $\geq 5$ & $\geq 2$ \\
\hline Zmodyfikowana skala genewska & Wersja oryginalna & Wersja uproszczona \\
\hline PE lub DVT w wywiadzie & 3 & 1 \\
\hline \multicolumn{3}{|l|}{ Tętno } \\
\hline $75-94 / \min$ & 3 & 1 \\
\hline$\geq 95 / \min$ & 5 & 2 \\
\hline Operacja lub złamanie w ciągu ostatniego miesiąca & 2 & 1 \\
\hline Krwioplucie & 2 & 1 \\
\hline Aktywna choroba nowotworowa & 2 & 1 \\
\hline $\begin{array}{l}\text { Bolesność żył głębokich kończyny dolnej podczas palpacji i jed- } \\
\text { nostronny obrzęk }\end{array}$ & 4 & 1 \\
\hline Wiek > 65 lat & 1 & 1 \\
\hline \multicolumn{3}{|l|}{ Prawdopodobieństwo kliniczne } \\
\hline \multicolumn{3}{|l|}{ Skala trzypoziomowa } \\
\hline Niskie & $0-3$ & $0-1$ \\
\hline Pośrednie & $4-10$ & $2-4$ \\
\hline Wysokie & $\geq 11$ & $\geq 5$ \\
\hline \multicolumn{3}{|l|}{ Skala dwupoziomowa } \\
\hline PE mało prawdopodobna & $0-5$ & $0-2$ \\
\hline PE prawdopodobna & $\geq 6$ & $\geq 3$ \\
\hline
\end{tabular}

DVT (deep vein thrombosis) - zakrzepica żył głębokich, PE (pulmonary embolism) - zatorowość płucna 
wiek, płeć, przewlekła choroba serca lub płuc, tętno, ciśnienie tętnicze, temperatura, częstość oddechów itp. [36, 37].

Rozpoznanie ZP opiera się na: pomiarze stężenia d-dimeru, badaniu echokardiograficznym, tomografii komputerowej, arteriografii płucnej, scyntygrafii płuc, rezonansie magnetycznym, ultrasonografii kompresyjnej żył (ryc. 2 i 3 , tab. 2) [38].

Prawidłowe stężenie d-dimeru wskazuje na małe prawdopodobieństwo ostrej ZP. Natomiast podwyższone stężenie d-dimeru nie jest przydatne do potwierdzania zatorowości płucnej, ponieważ jego wzrost obserwuje się również w innych stanach chorobowych, w których wytwarzana jest fibryna, np. stany zapalne, nowotwory, urazy, krwawienia, operacje [39].

Badanie echokardiograficzne - ZP prowadzi do przeciążenia ciśnieniowego i powiększenia prawej komory serca oraz jej niewydolności, poszerzenia tętnicy płucnej, nadciśnienia płucnego [40].

W badaniu echokardiograficznym poszerzenie PK jest obecne u 25\% pacjentów z zatorowością płucną. Dużą wartość prognostyczną WZP ma objaw $60 / 60$ oraz objaw McConella [5, 42]. Prawidłowy wynik badania echokardiograficznego nie wyklucza ZP [41].
Tomografia komputerowa jest badaniem z wyboru w przypadku podejrzenia ZP. Badanie to umożliwia dobrą wizualizacje tętnic płucnych do poziomu tętnic segmentalnych. Wynik TK jest wystarczającym kryterium dla wykluczenia choroby u pacjentów z niewysokim prawdopodobieństwem klinicznym ZP [43].

Scyntygrafia płuc jest badaniem z użyciem mniejszej ilości środka kontrastowego i niższej dawki promieniowania niż tomografia komputerowa. W związku z tym polecane jest stosowanie jej w przypadku chorych z ciężką niewydolnością nerek oraz dodatnim wywiadem alergicznym.

Arteriografia płucna - obecnie jest rzadko stosowana, gdyż mniej inwazyjna od niej jest angiografia CT , która ma podobną skuteczność obrazowania.

Rezonans magnetyczny obecnie jest również rzadziej stosowaną metodą w ocenie klinicznej, ze względu na niską czułość.

\section{Podsumowanie}

Żylna choroba zakrzepowo-zatorowa jest trzecią co do częstości występowania chorobą układu krążenia. Ryzyko zachorowania na zatorowość płucną zależy od płci,

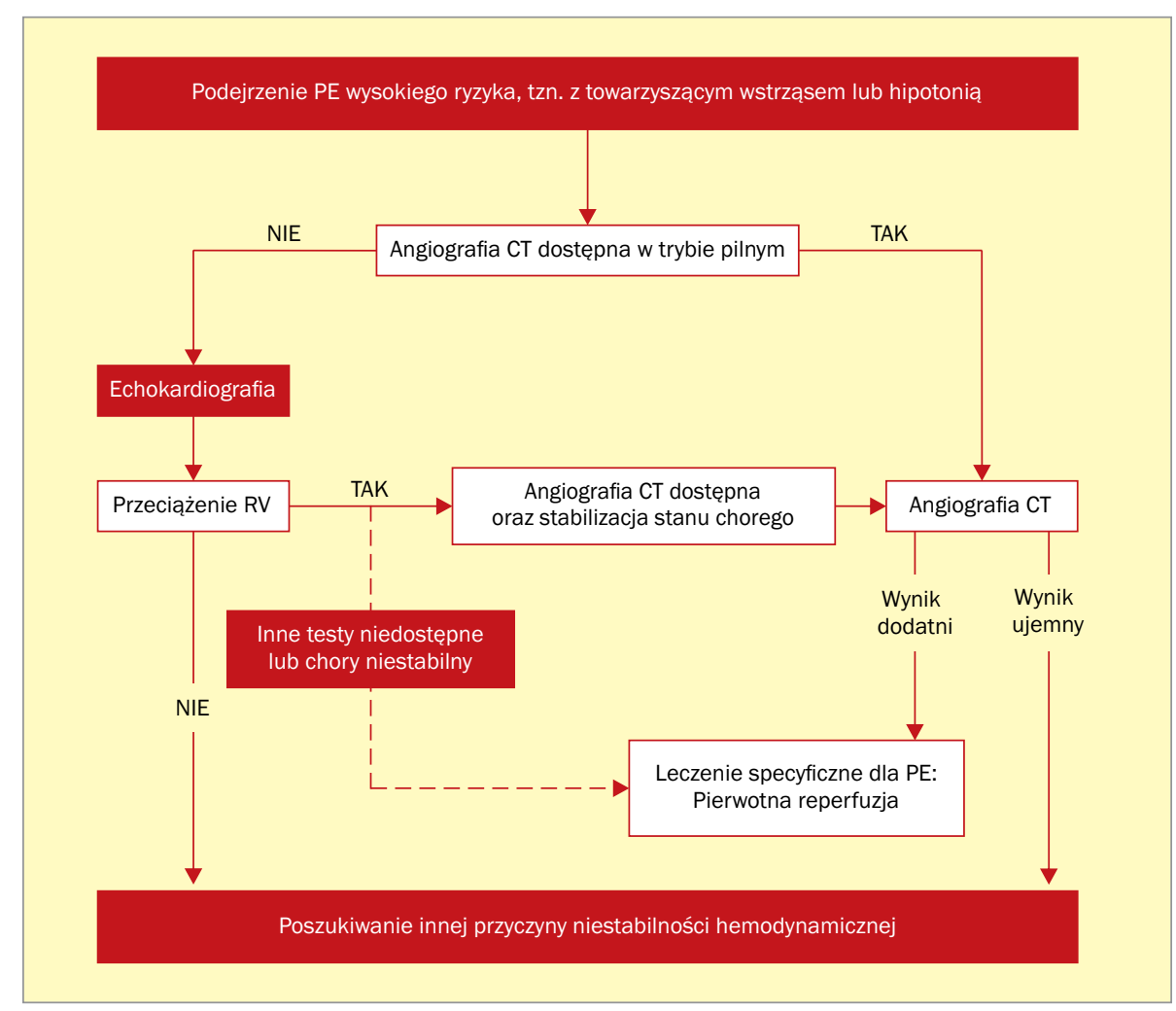

Rycina 2. Algorytm diagnostyczny dotyczący chorych z podejrzeniem zatorowości płucnej z grupy wysokiego ryzyka (z towarzyszącym wstrząsem lub hipotonią) [3]. CT (computed tomography) - tomografia komputerowa; RV (right ventricle) - prawa komora 


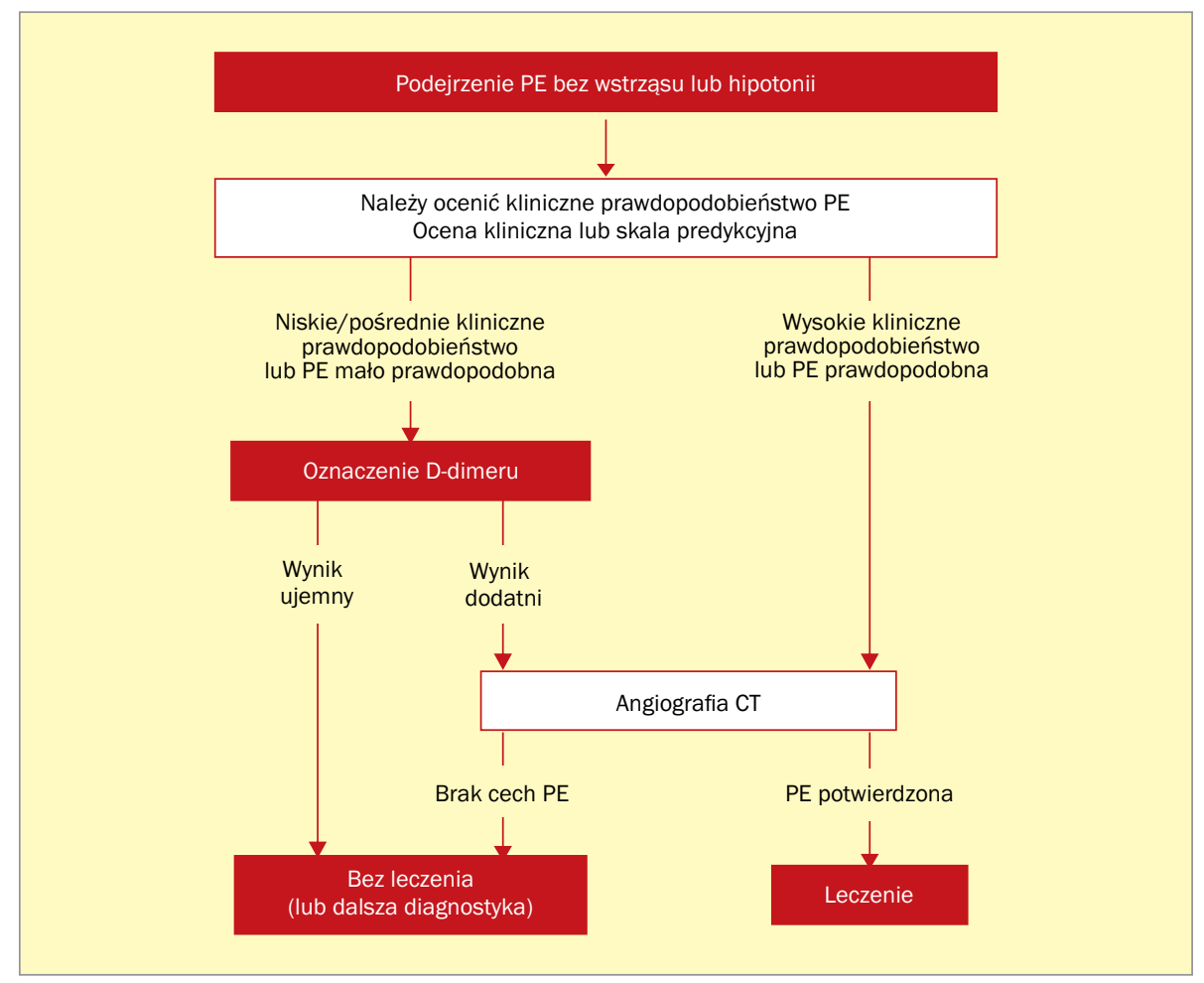

Rycina 3. Algorytm diagnostyczny dotyczący chorych z podejrzeniem zatorowości płucnej niewysokiego ryzyka [5]. CT (computed tomography) - tomografia komputerowa, RV (right ventricle) - prawa komora

Tabela 2. Kryteria diagnostyczne (na podstawie badań nieinwazyjnych) do rozpoznawania zatorowości płucnej u pacjentów bez wstrząsu lub hipotonii w zależności od prawdopodobieństwa klinicznego [5]

$\begin{array}{llll}\text { Kryterium diagnostyczne } & \text { Prawdopodobieństwo kliniczne PE } \\ \text { Wykluczenie PE } & \text { Niskie Pośrednie } & \text { Wysokie PE mało prawdopodobna PE prawdopodobna }\end{array}$

\section{D-dimer}

Wynik negatywny, test o wysokiej czułości

Wynik negatywny, test o umiarkowanej czułości

\section{Angiografia CT klatki piersiowej}

Prawidłowy wynik wielorzędowej CT

\section{Scyntygrafia V/Q}

Prawidłowa perfuzja płuc

Wynik niediagnostycznya

i wynik CUS wykluczający proksymalną DVT

\section{Potwierdzenie PE}

Angiografia CT klatki piersiowej wskazująca na co najmniej segmentowe PE

Wynik scyntygrafii V/Q wskazujący na wysokie prawdopodobieństwo PE

Wynik CUS potwierdzający proksymalną DVT

PE (pulmonary embolism) - zatorowość płucna, CT (computed tomography) - tomografia komputerowa, + ważne kryterium diagnostyczne (nie wymaga dalszych badań) - nieważne kryterium (dalsze badania obowiązkowe), \pm kryterium kontrowersyjne (należy rozważyć wykonanie dalszych badań), CT (computed tomography) - tomografia komputerowa, CUS (compression ultrasonography) - ultrasonografia kompresyjna proksymalnej części kończyn dolnych, DVT (deep vein thrombosis) - zakrzepica żył głębokich, PE (pulmonary embolism) - zatorowość płucna, scyntygrafia V/Q - wentylacyjno-perfuzyjna 
wskaźnika BMI oraz wieku badanej populacji. Ryzyko zwiększa się wraz z wiekiem, a począwszy od 40 roku życia rośnie dwukrotnie w każdej kolejnej dekadzie życia. Wysoce prawdopodobnym jest iż w przyszłości u coraz większej liczby pacjentów zdiagnozowana będzie ZP. Ponadto ryzyko zachorowania na zatorowość płucną jest większe u palaczy, osób otyłych, u osób z nieprawidłowym profilem lipidowym, miażdżycą, nadciśnieniem tętniczym oraz cukrzycą. Ryzyko wczesnego zgonu w zatorowości płucnej wysokiego ryzyka wynosi ponad 15\%, w zatorowości płucnej pośredniego ryzyka 3-15\%, a w zatorowości płucnej niskiego ryzyka jest mniejsze niż 1\%. Przeważająca część przypadków stanowi zatorowość płucna niewysokiego ryzyka. Klasyfikacja ciężkości ZP ma istotne znaczenie dla wykonania diagnostyki i wdrożenia odpowiedniego leczenia. Opiera się na ocenie stanu klinicznego chorego w chwili przyjęcia do szpitala. Diagnostykę zatorowości płucnej należy rozpocząć od ustalenia jej prawdopodobieństwa klinicznego.

W przypadku podejrzenia zatorowości płucnej niskiego i pośredniego ryzyka metodą pierwszego rzutu jest pomiar stężenia d-dimeru. U chorych z wysokim prawdopodobieństwem ZP nie wykonuje się pomiaru stężenia d-dimeru. Do pozostałych badań należą elektrokardiogram, badanie echokardiograficzne, gazometria oraz zdjęcie rentgenowskie. Badanie echokardiograficzne jest bardzo ważne zwłaszcza w przypadku chorych niestabilnych hemodynamicznie, gdy zbyt dużym ryzykiem jest transport chorego do pracowni tomografii komputerowej. Ostateczne wykluczenie lub potwierdzenie rozpoznania uzyskuje się dzięki angiografii lub tomografii komputerowej. Tomografia komputerowa jest obecnie tzw. złotym standardem w rozpoznawaniu zatorowości płucnej w Oddziałach Intensywnego Nadzoru Kardiologicznego [44].

\section{Abstract}

Venous thromboembolism includes two disease entities: deep vein thrombosis and pulmonary embolism. It is the third most frequent occurrence of cardiovascular disease. According to the latest statistics, the annual incidence of it is 100200 per 100,000 people. In most cases, pulmonary embolism is a consequence of deep veins thrombosis of the lower limbs, whereas non-thrombotic pulmonary embolism is quite rare. The factors predisposing to venous thromboembolism are individual factors, is permanent - related to the patient, and time factors - related to various clinical situations. Pulmonary embolism may also be idiopathic and may occur in the absence of any known risk factor. This paper presents etiopathogenesis, pathophysiology and the symptoms of pulmonary embolism. The work will be useful for doctors attending at emergency departments and the departments of cardiology and internal diseases. It will contribute to a more accurate recognition of that important disease entity.

Key words: venous thromboembolism, pulmonary embolism

Folia Cardiologica 2018; 13, 4: 309-317

\section{Piśmiennictwo}

1. Heit JA. The epidemiology of venous thromboembolism in the community. Arterioscler Thromb Vasc Biol. 2008; 28(3): 370-372, doi: 10.1161/ATVBAHA.108.162545, indexed in Pubmed: 18296591.

2. Cohen AT, Agnelli G, Anderson FA, et al. VTE Impact Assessment Group in Europe (VITAE). Venous thromboembolism (VTE) in Europe. The number of VTE events and associated morbidity and mortality. Thromb Haemost. 2007; 98(4): 756-764, indexed in Pubmed: 17938798.

3. Condliffe R, Kiely DG, Gibbs JSR, et al. Prognostic and aetiological factors in chronic thromboembolic pulmonary hypertension. Eur Respir J. 2009; 33(2): 332-338, doi: 10.1183/09031936.00092008, indexed in Pubmed: 18829679.
4. Fanikos J, Piazza G, Zayaruzny M, et al. Long-term complications of medical patients with hospital-acquired venous thromboembolism. Thromb Haemost. 2009; 102(4): 688-693, doi: 10.1160/TH09-040266, indexed in Pubmed: 19806254.

5. Konstantinides SV, Torbicki A, Agnelli G, et al. Task Force for the Diagnosis and Management of Acute Pulmonary Embolism of the European Society of Cardiology (ESC), ESC Committee for Practice Guidelines (CPG). Guidelines on the diagnosis and management of acute pulmonary embolism: the Task Force for the Diagnosis and Management of Acute Pulmonary Embolism of the European Society of Cardiology (ESC). Eur Heart J. 2008; 29(18): 2276-2315, doi: 10.1093/eurheartj/ehn310, indexed in Pubmed: 18757870. 
6. Goldhaber SZ, Visani L, De Rosa M. Acute pulmonary embolism: clinical outcomes in the International Cooperative Pulmonary Embolism Registry (ICOPER). Lancet. 1999; 353(9162): 1386-1389, indexed in Pubmed: 10227218.

7. Vaitkus PT, Leizorovicz A, Cohen AT, et al. PREVENT Medical Thromboprophylaxis Study Group. Mortality rates and risk factors for asymptomatic deep vein thrombosis in medical patients. Thromb Haemost. 2005; 93(1): 76-79, doi: 10.1160/TH04-05-0323, indexed in Pubmed: 15630494.

8. Zawilska K. Komentarz do zaktualizowanych polskich Wytycznych profilaktyki i leczenia żylnej choroby zakrzepowo-zatorowej. Med Prakt. 2005; 6: 157-167.

9. Bénard E, Lafuma A, Ravaud P. [Epidemiology of venous thromboembolic disease]. Presse Med. 2005; 34(6): 415-419, indexed in Pubmed: 15902870.

10. Kearon C. Epidemiology of venous thromboembolism. Semin Vasc Med. 2001; 1(1): 7-26, doi: 10.1055/s-2001-14668, indexed in Pubmed: 15199510.

11. Stein P, Hull R, Kayali F, et al. Venous Thromboembolism According to Age. Archives of Internal Medicine. 2004; 164(20): 2260, doi: 10.1001/archinte.164.20.2260.

12. Bounameaux H. Zakrzepica żył głębokich kończyn dolnych [w:] Ramelat AA, Monti M. Flebologia. 2003; 14: 163-169.

13. Zawilska K: Wytyczne profilaktyki i leczenia żylnej choroby zakrzepowo-zatorowej. Med Prakt 2005;6 (supl):1-56.Jędrusik P. Profilaktyka żylnej choroby zakrzepowo-zatorowej. Nowa Klin. 2003; 10: 923-929.

14. Nicolaides AN, Bergqvist D, Hull R. Consensus statement: prevention of venous thromboembolism. Int Angiol. 1997; 16: 3-38.

15. Laporte S, Mismetti P, Décousus $\mathrm{H}$, et al. RIETE Investigators. Clinical predictors for fatal pulmonary embolism in 15,520 patients with venous thromboembolism: findings from the Registro Informatizado de la Enfermedad TromboEmbolica venosa (RIETE) Registry. Circulation. 2008; 117(13): 1711-1716, doi: 10.1161/CIRCULATIONAHA.107.726232, indexed in Pubmed: 18347212.

16. $\mathrm{Ku} \mathrm{GH}$, White $\mathrm{RH}$, Chew HK, et al. Venous thromboembolism in patients with acute leukemia: incidence, risk factors, and effect on survival. Blood. 2009; 113(17): 3911-3917, doi: 10.1182/ /blood-2008-08-175745, indexed in Pubmed: 19088376.

17. Blanco-Molina A, Rota LL, Di Micco P, et al. RIETE Investigators. Venous thromboembolism during pregnancy, postpartum or during contraceptive use. Thromb Haemost. 2010; 103(2): 306-311, doi: 10.1160/TH09-08-0559, indexed in Pubmed: 20126835.

18. Blanco-Molina A, Trujillo-Santos J, Tirado R, et al. RIETE Investigators. Venous thromboembolism in women using hormonal contraceptives. Findings from the RIETE Registry. Thromb Haemost. 2009; 101(3): 478-482, indexed in Pubmed: 19277408.

19. Pomp ER, Lenselink AM, Rosendaal FR, et al. Pregnancy, the postpartum period and prothrombotic defects: risk of venous thrombosis in the MEGA study. J Thromb Haemost. 2008; 6(4): 632-637, doi: 10.1111/j.1538-7836.2008.02921.x, indexed in Pubmed: 18248600 .

20. Miller EJ, Marques MB, Simmons GT. Etiology of pulmonary thromboembolism in the absence of commonly recognized risk factors. Am J Forensic Med Pathol. 2003; 24(4): 329-333, doi: 10.1097/01. paf.0000097852.95794.3a, indexed in Pubmed: 14634470.

21. McIntyre KM, Sasahara AA. The hemodynamic response to pulmonary embolism in patients without prior cardiopulmonary disease. Am J Cardiol. 1971; 28(3): 288-294, indexed in Pubmed: 5155756.

22. Piazza G, Goldhaber SZ. Acute pulmonary embolism: part I: epidemiology and diagnosis. Circulation. 2006; 114(2): e28-e32, doi:
10.1161/CIRCULATIONAHA.106.620872, indexed in Pubmed: 16831989.

23. Wood KE. Major pulmonary embolism: review of a pathophysiologic approach to the golden hour of hemodynamically significant pulmonary embolism. Chest. 2002; 121(3): 877-905, indexed in Pubmed: 11888976

24. Miniati M, Prediletto R, Formichi B, et al. Accuracy of clinical assessment in the diagnosis of pulmonary embolism. Am J Respir Crit Care Med. 1999; 159(3): 864-871, doi: 10.1164/ajrccm.159.3.9806130, indexed in Pubmed: 10051264.

25. Thames MD, Alpert JS, Dalen JE. Syncope in patients with pulmonary embolism. JAMA. 1977; 238(23): 2509-2511, indexed in Pubmed: 578884.

26. Stein PD, Henry JW. Clinical characteristics of patients with acute pulmonary embolism stratified according to their presenting syndromes. Chest. 1997; 112(4): 974-979, indexed in Pubmed: 9377961.

27. Rodger MA, Carrier M, Jones GN, et al. Diagnostic value of arterial blood gas measurement in suspected pulmonary embolism. Am J Respir Crit Care Med. 2000; 162(6): 2105-2108, doi: 10.1164/ /ajrccm.162.6.2004204, indexed in Pubmed: 11112122.

28. Stein PD, Goldhaber SZ, Henry JW, et al. Arterial blood gas analysis in the assessment of suspected acute pulmonary embolism. Chest. 1996; 109(1): 78-81, indexed in Pubmed: 8549223.

29. Elliott CG, Goldhaber SZ, Visani L, et al. Chest radiographs in acute pulmonary embolism. Results from the International Cooperative Pulmonary Embolism Registry. Chest. 2000; 118(1): 33-38, indexed in Pubmed: 10893356.

30. Stein PD, Dalen JE, McIntyre KM, et al. The electrocardiogram in acute pulmonary embolism. Prog Cardiovasc Dis. 1975; 17(4): 247-257, indexed in Pubmed: 123074.

31. Konstantinides S, Torbicki A, Agnelli G, et al. Wytyczne ESC dotyczące rozpoznawania i postępowania w ostrej zatorowości płucnej w 2014 roku. Kardiologia Polska. 2014; 72(11): 997-1053, doi: 10.5603/ /kp.2014.0211.

32. Wells PS, Anderson DR, Rodger M, et al. Derivation of a simple clinical model to categorize patients probability of pulmonary embolism: increasing the models utility with the SimpliRED D-dimer. Thromb Haemost. 2000; 83(3): 416-420, indexed in Pubmed: 10744147.

33. Le Gal G, Righini M, Roy PM, et al. Prediction of pulmonary embolism in the emergency department: the revised Geneva score. Ann Intern Med. 2006; 144(3): 165-171, indexed in Pubmed: 16461960.

34. Konstantinides S, Torbicki A, Agnelli G, et al. Wytyczne ESC dotyczące rozpoznawania i postępowania w ostrej zatorowości płucnej w 2014 roku. Kardiologia Polska. 2014; 72(11): 997-1053, doi: 10.5603/ /kp.2014.0211.

35. Aujesky D, Perrier A, Roy PM, et al. Derivation and validation of a prognostic model for pulmonary embolism. Am J Respir Crit Care Med. 2005; 172(8): 1041-1046, doi: 10.1164/rccm.200506-8620C, indexed in Pubmed: 16020800.

36. Jiménez D, Aujesky D, Moores L, et al. RIETE Investigators. Simplification of the pulmonary embolism severity index for prognostication in patients with acute symptomatic pulmonary embolism. Arch Intern Med. 2010; 170(15): 1383-1389, doi: 10.1001/archinternmed.2010.199, indexed in Pubmed: 20696966.

37. Michiels JJ, Pattynama PM. Exclusion and diagnosis of pulmonary embolism by a rapid ELISA D-dimer test and noninvasive imaging techniques within the context of a clinical model. Clin Appl Thromb Hemost. 2000; 6(1): 46-52, indexed in Pubmed: 10726049.

38. Righini M, Aujesky D, Roy PM, et al. Clinical usefulness of D-dimer depending on clinical probability and cutoff value in outpatients with 
suspected pulmonary embolism. Arch Intern Med. 2004; 164(22): 2483-2487, doi: 10.1001/archinte.164.22.2483, indexed in Pubmed: 15596640.

39. Hiraoka N. [The role of echocardiography and venous ultrasonography in the diagnosis of acute pulmonary thromboembolism]. Nihon Rinsho. 2003; 61(10): 1731-1738, indexed in Pubmed: 14577296.

40. van der Pol LM, van der Hulle T, Cheung YW, et al. YEARS study group, Christopher Study Investigators, Christopher Study Investigators, Christoper Study Group. The role of helical CT in the diagnosis of pulmonary embolism. Pathophysiol Haemost Thromb. 2003; 33(5-6): 319-326, doi: 10.1159/000083821, indexed in Pubmed: 15692236.

41. Michiels JJ, Hoogsteden H, Pattynama PMT. Non-invasive diagnosis of pulmonary embolism, anno 2005. Acta Chir Belg. 2005; 105(1): 26-34, indexed in Pubmed: 15790199.
42. Konstantinides SV, Torbicki A, Agnelli G, et al. Task Force for the Diagnosis and Management of Acute Pulmonary Embolism of the European Society of Cardiology (ESC), ESC Committee for Practice Guidelines (CPG). Guidelines on the diagnosis and management of acute pulmonary embolism: the Task Force for the Diagnosis and Management of Acute Pulmonary Embolism of the European Society of Cardiology (ESC). Eur Heart J. 2008; 29(18): 2276-2315, doi: 10.1093/eurheartj/ehn310, indexed in Pubmed: 18757870.

43. Patel S, Kazerooni EA, Cascade PN. Pulmonary embolism: optimization of small pulmonary artery visualization at multi-detector row CT. Radiology. 2003; 227(2): 455-460, doi: 10.1148/radiol.2272011139, indexed in Pubmed: 12732699.

44. Lewczuk J. [Diagnosis of pulmonary embolism in COPD patients]. Pneumonol Alergol Pol. 2004; 72(11-12): 533-537, indexed in Pubmed: 16329357. 